\title{
Looking for Direction, Inspiration, Hope and Faith: The Search for a Visionary Leader
}

\author{
Eric Brunelle \& Jean-Philippe L'Écuyer ${ }^{1}$ \\ Department of Management \\ HEC Montreal, 3000 Chemin de la Côte Sainte-Catherine \\ Montreal, QC, Canada, H3T 2 A7.
}

\begin{abstract}
In an increasingly complex global competitive environment, vision has become indispensable for organizations to perform and survive. Vision is now considered one of the most important organizational dimensions.For this reason, organizations are constantly searching for visionary leaders to maintain their competitiveness. Although the concept of visionary leadership is well known, the antecedents of this form of leadership are less so. Thus, this study aims to demystify the nature of visionary leaders and investigatethe relationship between personality and visionary leadership. Based on theBigFive Inventory, the resultsreveala significant relationship for four of the five personality dimensions. Thus, openness to experience, conscientiousness, agreeablenessandextraversionallhave a positive relationship with visionary leadership.This information should help organizations identify and understand visionary leaders and recruit them more easily.
\end{abstract}

Keywords: Personality, Big Five Inventory, visionary leadership.

\section{Introduction}

The economic recovery of recent years and the increase in organizational complexity have transformed certain managerial imperatives within organizations (Stacey, 2010). One result has been the prioritization of a single organizational dimension: vision. Among others, a McKinsey \& Company study with a sample of 800 executives around the world revealed that vision now plays a key role in executives' mindset. Almost half of the executives surveyed in all industries considered vision to be the most important organizational dimension in today's context (McKinsey\& Company, 2010).

Several studies have shown that vision has a positive impact on organizational performance. The literature reveals that vision can enhance profit (Waldman,Ramirez, House, \&Puranam, 1991);share value (Agle, 1993);stakeholder performance; new product development; employee turnover (Lipton, 1996);customer satisfaction;and employee motivation, satisfaction, empowerment and commitment (Appelbaumet al., 2009; Dvir,Kass, \& Shamir, 2004; Hodgkinson, 1983; Kantabutra\& Avery, 2005). Moreover, vision facilitates the implementation of organizational strategies (Leithwood, 1994). Thus, executives appear to be correct in considering vision as a key dimension of organizations.

Consequently, to ensure that they are competitive, organizations seek visionary leaders. For example, the McKinsey\& Company (2010) study revealed that the ability to present a motivating vision of the future and to create optimism about its implementation is the leadership behaviormostvalued by executives today. Another study carried out byIBMwith 1,500 corporate executives around the world produced similar findings (IBM Global Business Services, 2010). It indicated that the most sought-after leaders in the current context of organizational complexity are visionary individuals with the courage to disrupt the status quo and contribute new ideas. However, the literature does not provide us with much information about the antecedents of a visionary leader. Some studies have shown a link between personality and leadership style. For example, Judge and Bono (2000) found a link between a leader's personality and the adoption of a transformational style.

\footnotetext{
${ }^{1}$ Department of Management, HEC Montreal, Montreal, QC, Canada
} 
Thus, they showed that three personality dimensions - agreeableness, openness to experience and extraversionwere positively associated with transformational leadership.

Although vision is integrated into transformational leadership, the fact remains that Judge and Bono's study does not reveal which personality traits are specifically related to being a visionary. From this perspective, this study was designed to develop our knowledge of the personality dimensions that predispose an individual to exercise visionary leadership.

\section{Review of the literature}

\subsection{From vision to visionary leadership}

Several authors have definedthe concept of vision.The consensus is that it involves a lively, vivid description (Lipton, 1996) of an idealized organizational future (Kouzes \& Posner, 1987) that will determine the organization's strategic vision (D'Amboise \& Bouchard, 1989). In addition, vision emphasizes social values and standards (Berson, Shamir, Avolio, \& Popper, 2001; Shamir, House, \& Arthur, 1993), while remaininganchored in a central ideology (Collins \&Porras, 1996).

The phenomenon of visionary leadership goes far beyond the simple fact that a leader has a vision of the future. In fact, the definition of a vision by the leader constitutes only $10 \%$ of the variance explaining visionary leadership (Jick, 2001). To fully exercise visionary leadership, an individual must also engage in a series of behaviors. Several authors have identified the key behaviors underlying visionary leadership. These are presented inTable 1.

Table1:The key behaviors of visionary leadership

\begin{tabular}{ll}
\hline \multicolumn{1}{c}{ Authors } & \multicolumn{1}{c}{ Key Behaviors } \\
\hline Kantabutra (2006);Nanus (1992); Quigley \\
$\begin{array}{l}\text { (1993); Robbins \& Duncan (1988); Sashkin } \\
\text { (1992); Wall, Solum, \&Sobol (1992) }\end{array}$ & $\begin{array}{l}\text { Development of a vision } \\
\text { Articulation of the vision } \\
\text { Communication of the vision } \\
\text { Implementation of the vision }\end{array}$ \\
Westley \&Mintzberg (1989) & $\begin{array}{l}\text { Development of a vision } \\
\text { Communication } \\
\text { Empowerment }\end{array}$ \\
Awamleh\& Gardner (1999); Conger (1989); & $\begin{array}{l}\text { Creation of the vision } \\
\text { Communication of the vision }\end{array}$ \\
Holladay \& Coombs (1993, 1994); & $\begin{array}{l}\text { Creation of the vision } \\
\text { Achievement of the vision over several } \\
\text { decades }\end{array}$ \\
Sashkin (1988) & $\begin{array}{l}\text { Creation of a vision by the leader } \\
\text { Communication of the vision } \\
\text { Implementation }\end{array}$ \\
\hline Groves (2006) & \\
\hline
\end{tabular}

Despite the varied nomenclature, we can summarize three major key behaviors associated with visionary leadership. A visionary leader should (1) develop a vision; then(2) this vision must be communicated by various oral and written means; and finally,(3) it must be implemented within the organization's practices. In other words, the leader must be able to continuously redefine the organization so that his/her vision can become a realitythere(Kouzes \& Posner, 2007; Sashkin, 1988).

\subsection{Leadership antecedents and leadership traits:Anallegedly obsolete quest that has been renewed}

In his literature review, Bass (2008) used two questions to delineate the intellectual quest underlying the search for leadership traits: (1)What traits distinguish leaders from other people?(2) What is the extent of those differences?For more than a century, this train of thought has sought to identify the traits that characterize leaders. It is often associated with the work of Stogdill (1948),which constitutes a review of 128 studies of leadership traits. His work made it possible to identify a phenomenal number of leadership traits: physiological, social and psychological. Although his list was rigorous, it did not enable the research stream to resist the ascendance of the situational approach in the 1960s. 
From then on, the vast majority of researchers adopted a paradigm that favored the predominance of the situation as a factor explaining the emergence and effectiveness of a leader within a group. In parallel, a minority of researchers continued the search for leadership traits. Thanks to Mann's (1959) experiments with job rotation, among others, the quest for leadership traits survived. Not only has this quest remained legitimate, it has been refined due to the influence of the situational approach. As of 1970, researchers in the leadership trait stream have overwhelminglyrejected the idea that someone can be born a leader. The determinism that had long been associated with leadership traitswas then replaced by the idea that individual characteristics can increase a person's chances of success as a leader in a particular situation (Van Fleet \&Yukl, 1986).

Starting in the 1960s, interest in the leadership trait approach declined for two main reasons. The first relates to the fact that researchers were incapable of anchoring the various traits identified in leaders in an integrated, coherent conceptual framework (Zaccaro, 2007). In other words, they were unable to explain the relationships between individuals' characteristic traits and whether or not they were leaders. The second reason was a consequence of the first: there was a frantic accumulation of unrelated leadership traits, each of which had low explanatory value. Anderson andScheier (1978) described this disorderly quest for leadership traits as producing a"myriadof characteristics,"while Conger andKanungo (1998) rightly characterized it as "overly simplistic." The study by Bono and Judge (2004) addressed these two problems head-on with a meta-analysis using Costa and McCrae's (1992)Five-Factor Model. In their study, the Five-Factor Model was used to structure leadership traits. The use of this model enabled them to (1) draw on the field of personality psychology to provide a theoretical explanation of leadership traits, and (2) organize and integrate the traits into a coherent whole. The Five-Factor Model is not only recognized as the best taxonomy for assessing leadership traits but also known to be the most reliable psychometric instrument in the field of personality (Bono \& Judge, 2004;Pervin\& John, 1999; Plaisant et al., 2010a). In particular, it hasstrong validity for all age groups and good potential for intercultural generalization(Costa \& McCrae, 1992; Digman, 1990; Plaisant et al., 2010a). Due to its psychometric validity and its ability to organize traits in a coherent whole, this model provides a valuable tool for researchers investigating the antecedents of leadership.

\section{Conceptual Framework}

\subsection{The Five-Factor Model and personality traits of visionary leaders}

Personality is defined as a set of relatively stable and general affective, emotional and dynamic characteristics in a person's way of reacting to the situations in which he/she finds himself/herself (Bloch et al., 2002). Personality is specific to each individual and distinguishes that person from others in their way of thinking, feeling and acting (Phipps \& Prieto, 2011).

The Five-Factor Model describes personality based on five dimensions: openness to experience, conscientiousness, extraversion, agreeableness and neuroticism (Costa \& McCrae, 1992; Moore \& McElroy, 2012; Plaisant et al., 2010b). Openness to experience is the personality dimension that is expressed in curiosity, open-mindedness, imagination, originality and the wish to explore new ideas. Conscientiousness is related to reliability, sense of responsibility, self-discipline, control and sense of achievement. Extraversion refers to the ease with which an individual approaches other people and engages in social interactions energetically and enthusiastically. Agreeableness concerns the individual's tendency to avoid conflict and be trustworthy, warm, courteous, modest and flexible. Neuroticism is the dimension that relates to distrust, embarrassment, expressed sadness and difficulty managing stress.

The next sections revisit the key behaviors of visionary leadership identified above and present how they may potentially be predicted with the help of an individual's personality traits.

\subsection{Openness to experience and visionary leadership}

The leader's development of a vision constitutes the basis of visionary leadership. It is the necessary but insufficient condition for exercising this kind of leadership. This vision does not emerge from nowhere; instead, it is slowly constructed and anchored in the leader's experience. WestleyandMintzberg (1989) illustrated this reality with an analogy to an artist. Thus, the visionary leader is compared to an artist who is preparing for a performance by rehearsing. The concept of rehearsal represents the experience the leader has acquired within the organization and the mastery of its context, including its products, market and technology. This mastery of the organizational context constitutes a prerequisite for describing a vision for the organization. 
Nevertheless, simply understanding the organizational context is insufficient to explain the emergence of a vision. The literature informs us that a visionary individual must also be capable of seeing the different possibilities the organization faces and imagining the new paths it could take in the future (Kouzes \& Posner, 2007). A visionary leader must be able to detect the presence of trends in the marketand to imagine an organizational future that will be desirable and coherent with the organization's strategic reality (D'Amboise \& Bouchard, 1989). The ease with which a visionary leader is able to detect trends, see possibilities and imagine the organization's future seems to be related to an acquired behavior - in other words, a personality trait-specifically,openness to experience. As we have seen, an individual who is open to experience seeks to explore new ideas and demonstrates imagination and creativity (McCrae, 1994). Thus, one might believe that this kind of person will find it easier to explore the reality of an organization and its market in order to detect trends and new approaches. As well, it seems likely that such a person's imaginative, creative side will help him/her to mentally design the image of the future organization, as seen in the vision. In that sense, an individual who is open to experience is likely to find it easier to develop a vision - one of the three key behaviors of visionary leadership. For that reason, we believe that someone who is markedly open to experience will be more likely to exercise visionary leadership. This led us to formulate the following hypothesis:

\section{H1: Openness to experience will have a positive relationship with visionary leadership.}

\subsection{Extraversion and visionary leadership}

Visionary leadership depends on good communication of the vision. This kind of leadership style is often depicted as being integrated with charismatic leadership. Thus, many authors have investigated how leaders inspirationally communicate a vision, a potent source of charisma (Awamleh\& Gardner, 1999; Bass, 1985; Baum,Edwin, \& Kirkpatrick, 1998; Bennis \& Nanus, 1985; Bird, 1989; House, 1976; Tichy\&Devanna, 1986; Westley \&Mintzberg, 1989). Studies have attempted to identify all the details of the various success factors for inspirational communication of a leader's vision. Although written communication of a vision has been proven to work (Baum et al., 1998; Bennis \&Nanus, 1985; Kouzes \& Posner, 2007), the oral channelis the most effective onefor exercising visionary leadership (Conger \&Kanungo, 1987;Groves, 2006; Locke, 1991). More specifically, nonverbal communication of positive emotions is very strongly involved in this practice. When visionary leaders communicate their vision, their eye contact, facial expressions, gestures and posture can considerably increase their leadership overtheir subordinates (Awamleh\& Gardner, 1999; Den Hartog\&Verburg, 1997; Groves, 2006; Holladay \& Coombs, 1994; Howell \& Frost, 1989). Groves (2006) demonstratedthat emotional expressiveness has a direct impact on visionary leadership. In other words, visionary leaders are capable of emotional expressiveness when communicating their vision and are able to make other people feel their enthusiasm and faith in the vision. This description of a visionary leader clearly seems to be closer to a personality trait than to an acquired behavior.

An individual's ability to express positive emotions is directly related to their level of extraversion. Extraverted individuals are constantly seeking excitement; they demonstrate enthusiasm and energyand communicate charismatically with others (Phipps \& Prieto, 2011). Forthisreason, we believe that a visionary leader's ability to communicate his/her vision in an inspiring way could well be linked to extraversion. It should be added that the visionary leader's confidence level has also been identified as a determining factor in his/her capacity to inspirationally communicate a vision (Ashkanasy\&Tse, 2000).

Confidence is another characteristic of extraverts (Phipps \& Prieto 2011). Thus, it seems clear that, because of their confidence, enthusiasm, energy and charisma, extraverted individuals will be more likely to exercise visionary leadership.

In addition, it should be noted that extraverts find it easy to approach other people and interact with them (Phipps \& Prieto, 2011). Although the literature does not specifically mention that this attitude is useful in exercising visionary leadership, one can easily defend such a claim. Because of the ease with which they approach and interact with other people, extraverts are likely to have many opportunities to communicate their vision; consequently, their level of visionary leadership will be higher. For all these reasons, we made the following hypothesis:

\section{H2: Extraversion will have a positive relationship with visionary leadership.}




\subsection{Conscientiousness and visionary leadership}

A key behavior of visionary leadership is implementation of the vision. Visionary leadersarepeople who constantly redefine the organization so that it is better aligned with their vision (Sashkin, 1988). In that way, they implement their vision within the organization. Concretely, this means that visionary leaders develop and deploy numerous policies and procedures that will make it possible to achieve their vision in the organization's daily operations (Kantabutra, 2006). Thus, suchleaders are much more than visionary individuals who communicate charismatically; they are also builders who work to make their vision a reality. Their leadership is exercised through their actions. This requires great self-determination, since these leaders must exert all the effort, patience and rigor needed to operationalize their vision. They are seen to have an obviousdesire to achieve the objectives defined by their vision and they work persistently to do so (Kouzes \& Posner, 2007).

The study of personality indicates that self-determination is a personality trait that originates in the dimensionofconscientiousness. Conscientious individuals have a pronounced sense of achievement, great selfdiscipline and a lot of diligence, which enable them to achieve their goals (Phipps \& Prieto, 2011).This leads us to believe that conscientious individuals are predisposed to become visionary leaders because they naturally possess the self-determination that is vital to implementing their vision within an organization. For these reasons, we made the following hypothesis:

\section{H3: Conscientiousness will have a positive impact on visionary leadership.}

\subsection{Neuroticism and visionary leadership}

Visionary leaders' ability to communicate an organizational vision makes them inspiring (Awamleh\& Gardner, 1999; Damen, van Knippenberg, \& van Knippenberg, 2008). Among other things, this capacity to inspire is related to the fact that visionary leaders are good at conveying positive emotions, which causes their subordinates to commit to their vision (Groves, 2006; Stam, van Knippenberg, \&Wisse, 2010).

The study of personality reveals that certain people naturally tend to feel and express predominantly negative emotions. This is the dimension called neuroticism, meaning that emotional negativity is more a consistent trait than an acquired behavior. So it is logical to believe that individuals with a high level of neuroticism will be less inclined to develop visionary leadership because they are more likely to express negative emotions, whereas the communicationof positive emotions is an essential component of this kind of leadership.

In addition, an individual with a high level of neuroticism tends to be vulnerable and mistrustful (Plaisant et al., 2010b). This characteristic is incompatible with the concept of visionary leadership, which is closely linked to stability, commitment to the future and organizational achievements (Kouzes \& Posner, 2007).

Although it may seem self-evident, it has been clearly proven that neuroticism is negatively correlated with leadership (Bono \& Judge, 2004; Hogan, Curphy, \& Hogan, 1994). More specifically, an individual with a high score for this dimension will be less able to communicate effectively and obtain buy-in from subordinates (Phipps \& Prieto, 2011). Visionary leaders are people who can communicate their vision in an inspiring way and get people to commit to it. This leads us to believe that this kind of leadership is incompatible with neuroticism, and therefore we formulated the following hypothesis:

\section{H4: Neuroticism will have a negative impact on visionary leadership.}

\subsection{Agreeableness and visionary leadership}

Although self-determination is crucial for visionary leadership, it is not a sufficient condition to ensure that a leader can implement his/her vision. Research shows that visionary leaders must also use tact to get subordinates to buy into their vision (Avery, 2004). To do this, they must be in harmony with their subordinates' needs (Gilmore, Shea,Useem, 1997),so that the latter will develop an emotional attachment to the vision. Subordinates' emotional attachment to the leader's vision is the keystone of visionary leadership because it allows the vision to be implemented and leadership to become more effective(Howell \& Shamir, 2005; Shamir et al., 1993).

Thus, a leader who can be described as visionary is very good at listening to subordinates and encourages them to talk about their aspirations in order to discover how their interests align with the vision (Kouzes \& Posner, 2007). These leaders have strong interpersonal sensitivity (Ashkanasy\&Tse, 2000)and find it easy to understand their subordinates' needs and determine what makes sense to them (Groves, 2006). This description of visionary leadership can easily be assimilated with the personality trait of agreeableness. 
An individual with a high level of agreeableness tends to feel sympathy, empathy and compassion for others. In addition, an agreeable individual pays attention to other people's needs and is considerate of them (Phipps \& Prieto, 2011). This leads us to believe that agreeable individuals are predisposed to exercise visionary leadership. Because they are empathetic and compassionate, it is reasonable to believe that they are naturally interested in their subordinates' needs and easily understand their personal concerns and ambitions. As well, their consideration for others pushes visionary leaders to take subordinates' wishes into consideration in most of their decisions. It has also been noted that visionary leaders tend to assign tasks to subordinates in a way that gives the lattermore power and flexibility (Kantabutra, 2006). They do this to give their subordinates a positive work experience, build their self-confidence and develop trusting relationships with them (Lussier \&Achua, 2000). Because they have more power to perform their own duties, the subordinates seek a common direction to give their efforts focus (Kantabutra, 2006). Since they have confidence in the visionary leader, they will refer to his/her vision to determine this common direction. In other words, they will work to make the leader's vision a reality because the leader believes in their potential and has earned their trust.

Once again, the trait of agreeableness seems to be strongly involved in this type of behavior. Agreeable individuals tend to trust other people, inspire trust in themselves, and support others (McCrae\& John, 1992; Phipps \& Prieto, 2011). One can therefore assume that individuals with a high level of agreeableness will find it easier to empower their subordinates, first of all because they want to support their professional development andalso because they trust them. These leaders are therefore more likely to delegate to subordinates and inspire confidence in themselves. As mentioned above, these are prerequisites for the subordinates referring to the vision in their work and striving to achieve it. For all these reasons, we proposed the following hypothesis:

\section{H5:Agreeableness will have a positive impact on visionary leadership.}

\section{Methodology}

\subsection{Procedure and participants}

In accordance withJohnsand Saks' (2005) recommendation, we conducted a quantitative correlational study. To do so, a self-administered electronic questionnaire was developed to collect data. Participants in the study were recruited from a national panel $^{2}$. Invitations were sent to 1,325 individuals,368 of whom responded, for a $28 \%$ response rate. AsTable 2 shows, most of our respondents were male (83.2\%), aged 45 and over (70.4\%) and the majority of respondents headed up an organizationwith fewer than 20 employees (67.1\%).

Table 2: Characteristics of sample

\begin{tabular}{|c|c|c|}
\hline Gender & Frequency & Percent \\
\hline Women & 62 & 16.8 \\
\hline Men & 306 & 83.2 \\
\hline Total & 368 & 100.0 \\
\hline Organization size & Frequency & Percent \\
\hline 1 to 4 employees & 82 & 22.3 \\
\hline 5 to 19 employees & 165 & 44.8 \\
\hline 20 to 49 employees & 86 & 23.4 \\
\hline 50 to 99 employees & 24 & 6.5 \\
\hline 100 to 499 employees & 11 & 3.0 \\
\hline Total & 368 & 10100.0 \\
\hline Age & Frequency & Percent \\
\hline Less than 25 & 1 & 0.3 \\
\hline 25 to 34 & 20 & 5.4 \\
\hline 35 to 44 & 78 & 21.2 \\
\hline 45 to 54 & 122 & 33.2 \\
\hline 55 and more & 137 & 37.2 \\
\hline Did not respond & 10 & 2.7 \\
\hline Total & 368 & 100.0 \\
\hline
\end{tabular}

\footnotetext{
${ }^{2}$ A research partnership was established with a national panel organization so that we could collect data from the institution's panel, a pan-Canadian panel of 2,000 executives. Panelists are motivated to participate in the institution's various studies because the aggregate results of the surveys are then provided exclusively to them.
} 


\subsection{Measures}

The questionnaire was developed in accordance with the procedure suggested byChurchill (1979). All the items used come from measurespresented in the literature and were previously validated. The measures used for each construct are presented below.

Personality. To measure subjects' personality traits, the study used the Big Five Inventory (BFI) developed by John,Donahue, and Kentle (1991). This tool has demonstrated good international, intercultural and intergenerational validity. It is the most widely used tool to measure personality traits. In its original form, the BFI has 44 items measured with a 5-pointLikertscale. To harmonize all the measures used in this studywithhow the panel works, a 10-pointLikertscale was used, ranging from $1=$ Not at all trueto $10=$ Completely true .

Visionary leadership. We measured respondents' visionary leadership with eight items developed by Page and Wong (2000). This measure was chosen becauseit had shown good psychometric properties. In addition, it is short, clear and addressed directly to the leader, which enabled us to create a self-administered questionnaire.A 10-pointLikertscale was used, ranging from $1=$ Not at all true to $10=$ Completely true.

Control variables. Based on previous research,we integrated the following control variables: gender, age and the organization size.

Finally, as Table 3 shows, the Cronbach's alphas of the scales for all the measures range between 0.72 and 0.85 , supporting the measures' reliability (Hair, Anderson, Tatham, \& Black, 1998).

Table 3: Cronbach's alphas for various measures

\begin{tabular}{|l|c|c|}
\hline \multicolumn{1}{|c|}{ Variables } & No. of items & Cronbach's Alpha \\
\hline Personality & & \\
Openness to experience & 10 & 0.791 \\
Extraversion & 8 & 0.778 \\
\hline Conscientiousness & 9 & 0.821 \\
\hline Neuroticism & 8 & 0.771 \\
\hline Agreeableness & 9 & 0.723 \\
\hline Visionary Leadership & 8 & 0.854 \\
\hline
\end{tabular}

\section{Results}

\subsection{Preliminaryanalysis}

Descriptive statistics and the correlation matrix are presented in Table 4. As illustrated, the mean results range between 6.89 and 7.70for all constructsexceptneuroticism;since this dimension is reversed, its mean is lower, at 3.96.These results meet our expectations and are consistent with the results presented in the literature.

Table 4: Correlation matrix

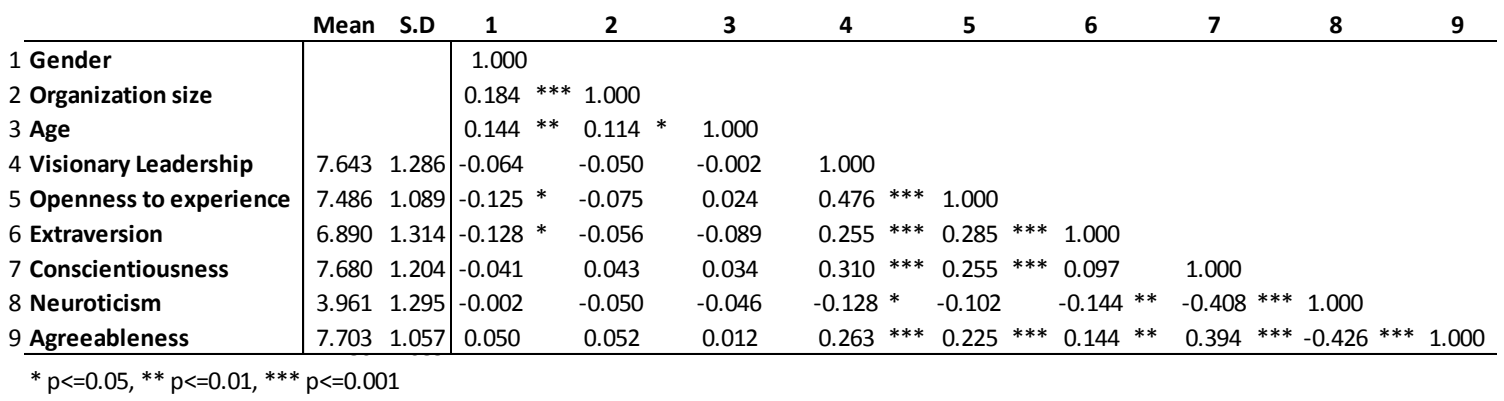

To be sure that our sample was representative, we compared the means with those obtained by Judge and Bono (2000) with a similar population. We found a variance of at most $6 \%$ in relation to Judge andBono'sresults.This indicates that our respondents are representative of a population of executives in terms of their BFI scores (Table $5)$. 
Table5: Comparison of BFI scores with a similar population

\begin{tabular}{|l|c|c|c|}
\cline { 2 - 4 } \multicolumn{1}{c|}{} & Judge \& Bono (2000) & This study & Difference \% \\
\hline Openness to experience & 6.99 & 7.49 & $-5 \%$ \\
\hline Extraversion & 7.24 & 6.89 & $4 \%$ \\
\hline Conscientiousness & 7.47 & 7.68 & $-2 \%$ \\
\hline Neuroticism & 4.53 & 3.96 & $6 \%$ \\
\hline Agreeableness & 7.39 & 7.7 & $-3 \%$ \\
\hline
\end{tabular}

\subsection{Tests of hypotheses}

To test our hypotheses, we did multiple linear regression analyses (Cohen,Manion, \& Morrison, 2007). The results of these analyses are presentedinTable6.They reveal that personality explains $28 \%$ of the variance in visionary leadership, making it an important antecedent.

Since many of the independent variables are significantly correlated, a variance inflation factor (VIF) diagnostic was used to test for multicollinearity. The most common cutoff threshold is a VIF above 10 (Hair et al., 1998). As we can see in Table 6, the VIF in this study is ranged between 1.042 and 1.345; thus, multicollinearity is not an issue here.

Table 6: Results of multiple linear regression analyses

\begin{tabular}{|c|c|c|c|c|}
\hline \multicolumn{5}{|c|}{ Dependent variable : Visionary Leadership } \\
\hline & Beta & t-Value & p-value & VIF \\
\hline Gender & 0.001 & 0.018 & 0.985 & 1.076 \\
\hline Organization size & -0.032 & -0.699 & 0.485 & 1.054 \\
\hline Age & -0.002 & -0.053 & 0.958 & 1.042 \\
\hline Openness to experience $(\mathrm{H} 1)$ & 0.376 & 7.726 & $0.000^{* * *}$ & 1.180 \\
\hline Extraversion (H2) & 0.118 & 2.498 & 0.013 * & 1.110 \\
\hline Conscientiousness (H3) & 0.186 & 3.587 & $0.000^{* * *}$ & 1.339 \\
\hline Neuroticism (H4) & 0.055 & 1.067 & 0.287 & 1.342 \\
\hline Agreeableness (H5) & 0.123 & 2.364 & 0.019 * & 1.345 \\
\hline $\mathbf{R}^{2}$ & 0.299 & & & \\
\hline Adjusted $\mathrm{R}^{2}$ & 0.283 & & & \\
\hline
\end{tabular}

The results of our analyses indicate that there is a significant positive relationship between the four dimensions of agreeableness $(\beta=0.123$, $t$-value $=2.364 *)$, conscientiousness $\left(\beta=0.186, t\right.$-value $\left.=3.587^{* * *}\right)$, Extraversion $(\beta=$ $0.118, t$-value $\left.=2.498^{*}\right)$ and Openness to experience $\left(\beta=0.376, t\right.$-value $\left.=7.726^{* * *}\right)$ and visionary leadership. These results support H1, H2, H3, and H5. There is no significant relationship between neuroticism and visionary leadership,soH4is not supported.

\section{Discussion and conclusion}

The objective of this study was to study the individual antecedents underlying the behaviors associated with visionary leadership, which is increasingly sought after by organizations. It was therefore important to identify the personality traits characterizing visionary leaders.

Our hypotheses predicted that all of the dimensions of personality would constitute determinants of visionary leadership. Our results showed that, except in the case of neuroticism, thesehypotheses were supported. Thus,openness to experience, extraversion, conscientiousnessand agreeableness all have a positive relationship with the degree of visionary leadership.

It is worth examining the results in more depth to highlight certain additional factors that contribute to our knowledge of the topic. First of all, the statistical analyses we conducted produced some interesting results, which confirmed the explanatory potential of the various personality dimensions in relation to an individual's visionary leadership. In fact, $28 \%$ of the variance in visionary leadership is explained solely by the leader's personality. That is a lot. Bono and Judge (2004) obtained more modest results, with an explained variance of $12 \%$. 
That means that personality is not only relevant but very probably central in explaining predispositions to visionary leadership, and even leadership in general. This seems completely logical in view of the definition of personality provided by Bloch et al. (2002) "A set of relatively stable, general affective, emotional and dynamic characteristics of a person's reactions to the situations in which he or she is placed.'It almost seems to be selfevident that an individual's stable, long-term affective and emotional characteristics must condition his/her leadership, both in terms of type and in terms of emergence or effectiveness. We claim that, because personality is a broad, overarching construct in a person's behavioral dynamic, it is a central element in understanding that person's visionary leadership behaviors, and leadership behaviors in general. Consequently, when it comes to both understanding the phenomenon and describing leadership traits, personality seems to be the key construct for future research.

We also; observed that openness to experienceis the personality dimension that has the greatest impact on visionary leadership. Openness to experiencecan easily justify the adoption of visionary behaviors given that such behaviors require one to identify possibilities, seize opportunities and creatively formulate a vision of the future (Kouzes \& Posner, 2007; Sashkin, 1988). Such behaviors are typical of an individual who is open to new experiences (Plaisant et al., 2010b).

The predominance ofopenness to experiencein explaining the variance in visionary leadership is a distinctive element of the results of this study. Earlier studies that associated the Five-Factor Model with transformational leadership had foundextraversionto be predominant in explaining the variance in transformational leadership (Bono \& Judge, 2004;Judge, Bono, Ilies, \& Gerhardt, 2002). Thus, our results support the idea that there is a real distinction between a visionary leader and a transformational leader. The evidence is the fact thatopenness to experienceconstitutes the primary predisposition for visionary leadership. A visionary leader is therefore someone who is more likely to be open to experience than to be extraverted. In other words, he/she is a creative person who seeks out new experiences and enjoys finding new solutions rather than a talkative person who likes to be in touch with many other people. These two different kinds of leadership call for two different kinds of personalities.

Finally, because the results were not significant, we cannot draw any conclusions regardingtheneuroticism personality dimension.However, this non-significant result does not necessarily mean that we must set the proposed theory aside. In fact, we believe that this result may be attributable to the composition of our study sample and the research design. Because the sample was made up of executives who had voluntarily signed up for the panelthat provided the information for this study, it is very probable that a social desirability bias affected their responses. Given that neuroticism is a "dark" personality trait, the subjects may have been in denial regarding their true level ofneuroticism.In sort, we believe that more studies using different methodologies will be necessary before the hypothesis that this personality trait is an antecedent of visionary leadership can be definitively rejected.

Despite the limitations of the study, we believe these results show that this is a promising approach that will allow us to make new discoveries in our quest for knowledge concerning the antecedents of leadership.

\section{References}

Agle, B.R. (1993). Charismatic chief executive officers: Are they more effective? An empirical test of charismatic leadership theory.Doctoral dissertation, Universityof Washington, Bothell, WA.

Anderson, C. R., \&Scheier, C. E. (1978). Locus of control, leader behavior and leader performance among management students.Academy of Management Journal, 24, 690-698.

Appelbaum, S.H., Carrière, D., Abi Chaker, M., Benmoussa, K., BasimElhawanmeh, B., \& Sash, S. (2009). RX for excessive turnover: Lessons in communicating a vision.Industrial and Commercial Training, 41, 240246, 368-379.

Ashkanasy, N. M., \&Tse, B. (2000). Transformational leadership as management of emotion: A conceptual review. In N. Ashkanasy, C. Hartel, \& W. Zerbe (Eds.), Emotions in the workplace: Research, theory and practice (pp. 221-235). Westport, CT: Quorum Books.

Avery, G. C. (2004). Paradigms of leadership: Theory and cases. Thousand Oaks, CA: Sage Publications. 
Awamleh, R., \&Gardner W. (1999). Perceptions of leader charisma and effectiveness: The effects of vision content, delivery, and organizational performance.LeadershipQuarterly, 10, 345-373.

Bass, B.M. (1985).Leadership and performance beyond expectations. New York: Free Press.

Bass, B. M. (2008) The Bass handbook of leadership: Theory, research, and managerial applications (4th ed.). New York: Free Press.

Baum, R. J., Edwin A. L., \&Kirkpatrick, S. A. (1998). A longitudinal study of the relation of vision and vision communication to venture growth in entrepreneurial firms.Journal of Applied Psychology, 83, 43-54.

Bennis, W.G., \&Nanus, B. (1985). Leaders: The strategies for taking charge.New York: Harper\&Row.

Berson, Y., Shamir, B., Avolio, B.J., \&Popper, M. (2001). The relationship between vision strength, leadership style and context.LeadershipQuarterly, 12, 53-73.

Bird, B. (1989). Entrepreneurial behavior. Glenview, IL:Scott, Foresman.

Bloch, H., Dépret, E., Gallo, A., Le Ny, J.-F., Reuchlin, M., \& Garnier, P. (2002). Dictionnaire fondamental de psychologie. Paris: Larousse.

Bono, J. E., \&Judge T. A. (2004).Personality and transformational and transactional leadership: A metaanalysis.Journal of Applied Psychology, 89, 901-910.

Churchill, G. A. (1979). A paradigm for developing better measures of marketing constructs. Journal of Marketing Research, 16, 64-73.

Cohen, L., Manion, L., \& Morrison, K. (2007). Research methods in education (6th ed.).London:Taylor\& Francis.

Collins, J.C., \&Porras, J.I. (1996). Building your company's vision. Harvard Business Review, SeptemberOctober, 65-77.

Conger, J. A. (1989). The charismatic leader: Behind the mystique of exceptional leadership. San Francisco, CA: Jossey-Bass.

Conger, J.A., \& Kanungo, N.R. (1987). Toward a behavioral theory of charismatic leadership in organizational settings.Academy of Management Review, 12,637-645.

Conger, J. A., \& Kanungo, R. N. (1998). Charismatic leadership in organizations. Thousand Oaks, CA: Sage Publications.

Costa, P.T., \& McCrae, R. (1992). NEO PI-R professional manual. Odessa, FL: Psychological Assessment Resources.

D'Amboise, G., \& Bouchard, S. (1989). De l'utilisation du concept de vision dans l'étude des organisations. Quebec, QC:Université Laval, Faculté des sciences de l'administration.

Damen, van Knippenberg, \& van Knippenberg (2008). Affective Match in Leadership: Leader Emotional Displays, Follower Positive Affect, and Follower Performance. Journal of Applied Social Psychology, 38, 868-902.

Den Hartog, D.N., \& Verburg,R. M. (1997). Charisma and rhetoric: Communicative techniques of international business leaders.LeadershipQuarterly, 8, 355-391.

Digman, J. M. (1990).Personality structure:Emergence of the five-factormodel.Annual Review of Psychology, 41, 417-440.

Dvir, T., Kass, N., \& Shamir, B. (2004). The emotional bond: Vision and organizational commitment among high-tech employees.Journal of Organizational Change Management, 17, 126-143.

Gilmore, T.N \& Shea, G.P, Useem, M. (1997). Side Effects of Corporate Cultural Transformations. Journal of Applied Behavioral Science, 33, $174-189$.

Groves, K.S. (2006). Leader emotional expressivity, visionary leadership, and organizational change.Leadership and Organizational Development Journal, 27, 566-583.

Hair, J. F., Anderson, R. E., Tatham, R. L., \&Black W. C. (1998). Multivariate data analysis(5th ed.).Upper Saddle River, NJ: Prentice Hall.

Hodgkinson, C. (1983). The philosophy of leadership. New York: St. Martin's Press.

Hogan, R., Curphy, G. J., \& Hogan, J. (1994). What we know about leadership: Effectiveness and personality.American Psychologist, 49,493-504.

Holladay, S., \& Coombs, W. (1993). Communicating visions: An exploration of the role of delivery in the creation of leader charisma.Management Communication Quarterly, 6,405-427.

Holladay, S., \& Coombs, W. (1994). Speaking of visions and visions being spoken.Management Communication Quarterly, 8, 165-189. 
House, R.J. (1976). A 1976 theory of charismatic leadership. Toronto, ON: University of Toronto, Faculty of Management Studies.

Howell, J. M., \& Frost, P.J. (1989). A laboratory study of charismatic leadership.Organizational Behavior and Human Decision Processes, 43, 243-269.

Howell, J. M., \& Shamir, B. (2005). The role of followers in the charismatic leadership process: Relationships and their consequences.Academy of Management Review, 30, 96-112.

IBM Global Business Services. (2010). Capitalizing on complexity: Insights from the Global Chief Executive Officer Study. Somers, NY: IBM Corporation.

Jick, T. (2001). Vision is 10\%, implementation is the rest.Business Strategy Review, 12, 36-38.

John, O. P., Donahue E. M.,\&Kentle,R. L. (1991). The Big Five Inventory-Versions $4 a$ and 54.Berkeley,CA:University of California, Berkeley, Institute of Personality and Social Research.

Johns, G., \& Saks, A. M. (2005). Organizational behaviour: Understanding and managing life at work (7th ed.).Toronto, ON: Pearson Education Canada.

Judge, T.A., \&Bono, J.E. (2000). Five-factor model of personality and transformational leadership.Journal of Applied Psychology, 85, 751-765.

Judge, T. A., Bono, J. E., Ilies, R., \&Gerhardt, M. (2002). Personality and leadership: A qualitative and quantitative review.Journal of Applied Psychology, 87, 765-780.

Kantabutra, S. (2006). Follower effects in the visionary leadership process. Journal of Business and Economic Research, 4, 57-66.

Kantabutra, S., \& Avery, G. C. (2005). Essence of shared vision: Empirical investigation.New Zealand Journal of Human Resources Management, 5, 1-28.

Kouzes, J. M., \&Posner, B.Z. (1987). The leadership challenge: How to get extraordinary things done in organizations.San Francisco, CA: Jossey-Bass.

Kouzes, J. M., \&Posner, B.Z. (2007). The leadership challenge (4th ed.). San Francisco, CA: John Wiley \& Sons/Jossey-Bass.

Leithwood, K. (1994). Leadership for school restructuring.Educational Administration Quarterly, 30, 498-518.

Lipton, M. (1996). Demystifying the development of an organizational vision.Sloan Management Review, 37,8392.

Locke, E. A. (1991). The motivation sequence, the motivation hub, and the motivation core.Organizational Behavior and Human Decision Processes, 50,288-299.

Lussier, R. N., \&Achua, C. (2000). Leadership: Theory, application and skill development. Cincinnati, OH: Thomson South-Western.

Mann, R. D. (1959). A review of the relationship between personality and performance in small groups.Psychological Bulletin, 56, 241-270.

McCrae, R. R. (1994). Openness to experience: Expanding the boundaries of Factor V. European Journal of Personality, 8, 251-272.

McCrae, R. R., \& John, O. P. (1992). An introduction to the five-factor model and its applications. Journal of Personality, 2, 175-215.

McKinsey \& Company. (2010). Women leaders, a competitive edge in and after the crisis.

Moore, K., \&McElroy, J. C. (2012). The influence of personality on Facebook usage, wall posting and regret.Computers in Human Behavior, 28, 267-274.

Nanus, B. (1992).Visionary leadership: Creating a compelling sense of direction for your organization.San Francisco, CA: Jossey-Bass.

Page, D., \& Wong, P. T. P (2000). A conceptual framework for measuring servant-leadership. In S. Adjibolooso (Ed.),Thehuman factor in shaping the course of history and development (pp. 69-109). New York:University Press of America.

Pervin, L. A.,\& John, P. O. (1999). Handbook of personality: Theory and research.NewYork:Guilford Press.

Phipps, S. A., \& Prieto, L. C. (2011). The influence of personality factors on transformational leadership: Exploring the moderating role of political skill.International Journal of Leadership Studies, 6, 430-447.

Plaisant, O., Guertault, J., Courtois, R., Réveillère, C., Mendelsohn, G.A., \&John, O.P. (2010a). Histoire du "Big Five": OCEAN des cinq grands facteurs de la personnalité. Introduction du Big Five Inventory français ou BFI-FR.Annales Médico-Psychologiques, 168,97-106. 
Plaisant, O., Guertault, J., Courtois, R., Réveillère, C., Mendelsohn, G.A., \&John, O.P. (2010b). Validation par analyse factorielle du Big Five Inventory français (BFI-Fr). Analyse convergente avec le NEO-PIR.Annales Médico-Psychologiques, 168,97-106.

Quigley, J. V. (1993). Vision: How leaders develop it, share it, and sustain it. New York: McGraw-Hill.

Robbins, S. R., \& Duncan, R. B. (1988). The role of the CEO and top management in the creation and implementation of strategic vision. In D. C. Hambrick (Ed.), The executive effect: Concepts and methods for studying top managers (pp. 137-162). Greenwich, CT: JAI Press.

Sashkin, M. (1988). The visionary leader.In J. A.Conger\&R. N. Kanungo (Eds.), Charismatic leadership in organizations: The elusive factor in organizational effectiveness(pp. 122-160). San Francisco, CA: Jossey-Bass.

Shamir, B., House, R. J., \& Arthur, M. B. (1993). The motivational effects of charismatic leadership: A selfconcept based theory.Organizational Science, 4, 577-594.

Stacey, R. D. (2010). Complexity and organizational reality: Uncertainty and the need to rethink management after collapse of investment capitalism (2nd ed.). New York: Routledge.

Stam, D., van Knippenberg, D., \&Wisse, B. (2010). Focusing on followers: The role of regulatory focus and possible selves in visionary leadership.LeadershipQuarterly, 21, 457-468.

Stogdill, R. M. (1948). Personality factors associated with leadership: A survey of the literature.Journal of Psychology, 25, 35-71.

Tichy, N.M., \&Devanna, M.A.(1986). The transformational leader. New York: Wiley.

Van Fleet, D.D., \&Yukl, G. (1986). Military leadership: An organizational perspective. Greenwich, CT: JAI Press.

Waldman, D.A., Ramirez, G.G., House, R.J.,\&Puranam, P. (2001). Does leadership matter? CEO leadership attributes and profitability under conditions of perceived environmental uncertainty.Academy of Management Journal, 44, 134-143.

Wall, B., Solum, R. S., \&Sobol, M. R. (1992). The visionary leader. Rocklin, CA: Prima Publishing.

Westley, F., \&Mintzberg, H. (1989). Visionary leadership and strategic management.Strategic Management Journal, 10, 17-32.

Zaccaro, S. J. (2007). Trait-based perspective of leadership.The American Psychologist, 6, 6-16. 